\title{
OPTIMALISASI PENGGUNAAN PROYEKTOR DALAM PEMBELAJARAN PADA MATA PELAJARAN I.P.A
}

\author{
Siska Nasfa Ayu Sulastri, Hanifuddin Jamin dan Maya Agustina \\ Guru SD An Nahla, Dosen Prodi Pendidikan Guru Madrasah Ibtidaiyah \\ STAIN Teungku Dirundeng Meulaboh \\ Emai: 1; Siskanasfa01@gmail.com 2; hanifstainmbo@gmail.com 3; \\ mayaagustn@staindirundeng.ac.id
}

\begin{abstract}
Abstrak
Tujuan yang hendak dicapai dalam penelitian ini untuk mengetahui penggunaan media proyektor dalam pembelajaran I.P.A dan untuk mengetahui dampak penggunaan media proyektor dalam pembelajaran I.P.A. Penggunaan media belajar proyektor dapat membantu guru agar dapat mengembangkan teknik pengajaran sehingga dapat memperoleh hasil yang lebih maksimal. Penggunaan proyektor secara optimal di dalam proses belajar mengajar khususnya pada mata pelajaran I.P.A, diharapkan mampu meningkatkan motivasi siswa dalam belajar. Penelitian ini berjenis penelitian kepustakaan dengan teknik pengumpulan data dokumen dalam penelitian ini berupa jurnal-jurnal dari penelitian terdahulu yang berkaitan dengan penggunaan proyektor dalam pembelajaran I.P.A. Dari pembahasan yang dilakukan dapat disimpulkan bahwa penggunaan media proyektor dalam pembelajaran I.P.A bermanfaat sebagai alat presentasi, sebagai media Informasi dan sebagai pemutar Video. Selain itu penggunaan media belajar proyektor pada mata pelajaran I.P.A dapat meningkatkan minat, motivasi siswa dalam belajar sehingga memberikan dampak yang positif dalam peningkatan prestasi siswa.
\end{abstract}

\section{Kata Kunci : Optimalisasi, Proyektor dan Pelajaran I.P.A}

\section{absract}

The objectives to be achieved in this study are to determine the us of projector media in I.P.A learning and to determine the impact of using projector media in I.P.A learning. The use of projector learning media can help teachers develop teaching techniques so that they can get maximum result. Optimal use of the projector in the teaching and learning process, especially in science subjects, is expected to increase student motivation in learning. This research is a library research type with document data collection techniques in this study in the from of journals from previous research related to the us of projectors in I.P.A learning. From the discussion, it can be concluded that the us of projectors in I.P.A learning is useful as a presentation tool, as an information medium and as a video player. In additiom, the us of projector learning media in science subjects can increase student motivation in learning so that it has apositive impact in increasing student achievement.

Keywords : optimalization, projector, I.P.A lessons 


\section{PENDAHULUAN}

Belajar adalah perbuatan yang sangat komplek, proses yang berlangsung dalam otak manusia. Keterlibatan dan keaktifan siswa dalam proses belajar mengajar beraneka ragam, seperti mendengarkan ceramah, mendiskusikan, membuat suatu alat, membuat laporan pelaksanaanpelaksanaan tugas dan sebagainya. "Keaktifan siswa yang berbeda-beda itu dapatlah dikelompokkan atas aktivitas fisik dan non fisik seperti mental intelektual dan emosional. (Abu Ahmadi dan Joko Tri Prasetia 2005:120).

Dalam usaha meningkatkan mutu pendidikan di Indonesia yang paling dominan adalah melalui proses belajar mengajar. Proses belajar mengajar pada hakikatnya adalah proses komunikasi antara guru dan siswa atau siswa dengan siswa dalam menyampaikan pesan dari guru kepada siswa, pesan-pesan tersebut berupa isi ajaran dan didikan yang ada di kurikulum dituangkan oleh guru atau sumber lain kedalam simbol-simbol komunikasi visual maupun verbal. Pada hakikatnya dalam proses belajar mengajar merupakan sebuah sistem, yang didalamnya memiliki berbagai komponen diantaranya guru dan peserta didik, bahan pelajaran (alat peraga), metode dan strategi belajar mengajar, alat atau media, sumber pelajaran dan evaluasi yang saling bekerja sama dan terpadu untuk mencapai tujuan pembelajaran (Arief Sadiman, 2000:6).

Semua komponen di atas sangat mendukung proses belajar mengajar. Diantara komponen tersebut adalah metode mengajar yang harus diperhatikan dalam proses pengajaran. Sehingga setiap proses pengajaran yang dilaksanakan oleh guru mencapai tujuan yang telah direncanakan. Abu Ahmadi dan Joko Prasetia (2005:52) mengatakan bahwa. "Apabila metode yang dipakai oleh guru dalam proses belajar mengajar kurang bervariasi, maka situasi proses belajar mengajar cenderung bersifat pasif dan konsekuensinya mengurangi motivasi siswa dalam mengikuti proses belajar mengajar. Sebaliknya apabila metode yang digunakan sesuai dengan materi, maka proses belajar mengajar akan efektif serta meningkatkan motivasi siswa, tentunya siswa akan aktif".

Dalam proses pembelajaran kehadiran media pembelajaran mempunyai arti yang cukup penting. Karena dalam kegiatan tersebut ketidakjelasan bahan yang disampaikan dapat dibantu dengan menghadirkan media sebagai perantara. Kerumitan bahan yang disampaikan kepada siswa dapat disederhanakan dengan bantuan media. Media dapat mewakili apa yang kurang mampu guru ucapkan melalui kata-kata atau kalimat tertentu. Bahkan keabstrakan bahan dapat dikonkretkan dengan kehadiran media. Dengan demikian, anak didik lebih mudah mencerna bahan dari pada tanpa bantuan media (Syaiful Bahri Djamarah, 2006:27).

Keberadaan media dalam proses pembelajaran, terutama Ilmu Pengetahuan Alam memiliki bermacam-macam fungsi dan manfaatnya. Dalam proses pembelajaran tentu fungsi media diarahkan pada suatu pengaruh ke arah pencapaian tujuan pendidikan. Pencapaian tujuan lebih baik diwujudkan dengan menggunakan alat yang sesuai dengan sifat tujuan. Pada saat ini guru sudah sadar akan kepentingan alat-alat pengajaran dalam proses pendidikan. Dengan semakin majunya ilmu pengetahuan diharapkan guru dapat menginovasikan alat-alat khusus untuk tujuan pendidikan tersebut (Winarno Surachman, 2003:27).

Untuk mencapai tujuan yang diharapkan media pembelajaran sangat diperlukan, salah satu media yang sering digunakan LCD Proyektor. LCD Proyektor adalah alat yang dirancang sedemikian rupa sehingga dapat memproyeksikan transparansi ke arah layar lewat atas atau samping kepala orang yang menggunakannya. Berbagai objek atau pesan yang dituliskan atau digambarkan pada transparansi bisa diproyeksikan lewat LCD Proyektor, misalnya gambar, diagram, peta, grafik, batasan dan sebagainya (Yulia Utami, 2017:53).

Penggunaan media Proyektor dapat membantu guru agar dapat mengembangkan teknik pengajaran sehingga dapat memperoleh hasil yang lebih maksimal. Melihat 
sedemikian pentingnya proses belajar mengajar dan peranan guru, maka dalam pengembangan ilmu pengetahuan perlu dikembangkan sikap dan prilaku belajar yang dapat menumbuhkan minat belajar secara wajar (Joko Sarminto :2).

\section{KAJIAN TEORI}

\section{A. Media Pembelajaran}

Media belajar termasuk bagian pembelajaran yang mempengaruhi interaksi belajar mengajar di kelas. Kata media berasal dari bahasa latin yang merupakan bentuk jamak dari kata medium yang berarti perantara atau pengantar. Dengan demikian media merupakan wahana penyalur informasi belajar atau penyalur pesan. Bila media adalah sumber belajar, maka secara luas media dapat diartikan "dengan manusia, benda ataupun peristiwa yang memungkinkan anak didik memperoleh pengetahuan dan keterampilan"(Syaiful Bahri Djamarah dan Aswan Zein, 2006:120).

Abuddin Nata (2005:299) dalam bukunya Perspektif Islam tentang Strategi Pembelajaran menjelaskan media pengajaran sesungguhnya merupakan bagian dari sumber pengajaran yang di dalamnya pengajaran disampaikan. Dalam hal ini terdapat dua unsur yang terkandung dalam media pengajaran yaitu (1) pesan atau bahan pengajaran yang akan disampaikan yang selanjutnya disebut sebagai perangkat lunak (software); (2) alat penampilan atau perangkat keras (hardware).

Dengan melihat uraian di atas, maka media pembelajaran merupakan alat atau sarana yang digunakan oleh seorang pengajar yang berbentuk perangkat keras (hardware) dan perangkat lunak (software), untuk menyampaikan pesan yang tertuang dalam materi ajar, baik dalam bentuk materi dan non materi yang semua yang diajarkan oleh guru harus berdasarkan kepada ajaran dalam agama.

\section{B. Proyektor}

LCD Proyektor merupakan salah satu perangkat yang digunakan untuk presentasi multimedia pada berbagai kegiatan, seperti pendidikan maupun perkantoran Penggunaan LCD Proyektor bagi kegiatan pendidikan dapat memberikan banyak manfaat bagi mahasiswa yang mengikuti kegiatan perkuliahan. Demikian halnya, bagi dosen sebagai tenaga pengajar perguruan tinggi, penggunaan LCD Proyektor dapat memudahkan dosen dalam menyampaikan materi secara interaktif melalui perangkat notebook yang dimiliki oleh dosen.

LCD Proyektor merupakan salah satu media elektronik yang dapat digunakan oleh guru dalam proses belajar mengajar. Media LCD Proyektor dapat membantu guru untuk lebih mudah dalam mengajar dan siswa lebih mudah dalam menerima pembelajaran. Menggunakan media LCD Proyektor juga dapat membantu guru agar dapat mengembangkan teknik pengajaran sehingga dapat memperoleh hasil yang lebih maksimal. Melihat sedemikian pentingnya proses belajar mengajar dan peranan guru, maka dalam pengembangan ilmu pengatahuan perlu dikembangkan sikap dan prilaku belajar yang dapat menumbuhkan minat belajar secara wajar. Untuk itu pembelajaran dengan menggunakan media pembelajaran, khususnya media LCD Proyektor dapat dijadikan alternatif dalam hal tersebut.

Media LCD Proyektor adalah sebuah alat proyeksi yang mampu menampilkan unsurunsur media seperti gambar, teks, video, animasi, video baik secara terpisah maupun gabungan diantara unsur-unsur media tersebut dan dapat dikoneksikan dengan perangkat elektronika lainnya yang digunakan guru untuk media presentasi yang bersifat menyalurkan pesan dan dapat merangsang pikiran, perasaan, dan kemauan siswa sehingga dapat menolong terjadinya proses belajar pada dirinya.( Joko Sarminto :2) 


\section{Suasana Belajar}

Suasana kelas merupakan wahana paling dominan bagi terselenggaranya proses pembelajaran di sekolah. Kelas merupakan tempat yang begitu penting dalam proses pembelajaran di sekolah. Dalam kegiatan belajar mengajar terdapat dua hal yang turut menentukan berhasil tidaknya suatu proses belajar mengajar, yaitu pengelolaan kelas dan pengajaran itu sendiri. Kedua hal itu saling tergantung. Keberhasilan pengajaran, dalam arti tercapainya tujuan-tujuan intruksional sangat bergantung pada kemampuan mengelola kelas. Kelas yang baik dapat menciptakan situasi yang memungkinkan siswa belajar sehingga merupakan titik awal keberhasilan pengajaran (Dwi Faruqi, 2018: 294).

I.P.A berkaitan dengan cara mencari tahu tentang alam secara sistematis, sehingga I.P.A bukan hanya penguasaan kumpulan pengetahuan yang berupa fakta-fakta, konsep-konsep, atau prinsip-prinsip saja tetapi juga merupakan suatu proses penemuan (Permendiknas Nomor 22 Tahun 2006:3).

Ningsih juga memaparkan bahwa I.P.A merupakan pengetahuan hasil kegiatan manusia yang bersifat aktif dan dinamis tiada henti-hentinya serta diperoleh melalui metode tertentu yaitu teratur, sistematis, berobjek, bermetode, dan berlaku secara universal. I.P.A merupakan pengetahuan dari hasil kegiatan manusia yang diperoleh dengan menggunakan langkahlangkah ilmiah yang berupa metode ilmiah dan didapatkan dari hasil eksperimen atau observasi yang bersifat umum dan akan terus disempurnakan. I.P.A merupakan produk dan proses yang tidak dapat dipisahkan. Produk I.P.A ialah berupa fakta-fakta, hukum-hukum, konsep-konsep, prinsip-prinsip, teori-teori, klasifikasi, struktur, dan lainnya. Sedangkan proses I.P.A ialah cara kerja memperoleh hasil tersebut yang biasanya terkandung cara kerja, sikap, dan cara berpikir kemajuan I.P.A yang pesat disebabkan oleh proses ini (Ningsih, 2012:37).

Unsur yang sangat penting dalam pembelajaran I.P.A mencakup sikap, proses dan produk. Hal ini sebagaimana hakikat pembelajaran I.P.A menurut Depdiknas ( $2006: 3$ ) yang meliputi tiga unsur utama yaitu:

a. Sikap: rasa ingin tahu tentang benda, fenomena alam, makhluk hidup, serta hubungan sebab akibat yang menimbulkan masalah baru yang dapat dipecahkan melalui prosedur yang benar, I.P.A bersifat open ended;

b. Proses: prosedur pemecahan masalah melalui metode ilmiah, metode ilmiah meliputi penyusunan hipotesis, perancangan eksperimen atau percobaan, evaluasi, pengukuran, dan penarikan kesimpulan;

c. Produk: berupa fakta, prinsip, teori, dan hukum.

I.P.A juga mempunyai tujuan yang hendak dicapai diantaranya:

a. Meningkatkan keyakinan terhadap kebesaran Tuhan Yang Maha Esa berdasarkan keberadaan, keindahan dan keteraturan alam ciptaan-Nya.

b. Mengembangkan pemahaman tentang berbagai macam gejala alam, konsep dan prinsip I.P.A yang bermanfaat dan dapat diterapkan dalam kehidupan sehari-hari.

c. Mengembangkan rasa ingin tahu, sikap positif, dan kesadaran terhadap adanyahubungan yang saling mempengaruhi antara I.P.A, lingkungan, teknologi, dan masyarakat.

d. Melakukan inkuiri ilmiah untuk menumbuhkan kemampuan berpikir, bersikap dan bertindak ilmiah serta berkomunikasi.

e. Meningkatkan kesadaran untuk berperan serta dalam memelihara, menjaga, dan melestarikan lingkungan serta sumber daya alam.

f. Meningkatkan kesadaran untuk menghargai alam dan segala keteraturannya sebagai salah satu ciptaan Tuhan. 
g. Meningkatkan pengetahuan, konsep, dan keterampilan I.P.A sebagai dasar untuk melanjutkan pendidikan ke jenjang selanjutnya.

\section{Faktor-Faktor yang Mempengaruhi Suasana Kelas Saat Belajar}

Pengelolaan kelas sangat penting untuk terciptanya suasana belajar yang menyenangkan. Banyak faktor yang mempengaruhi pengelolaan kelas antara lain kurikulum, bangunan dan sarana, guru, siswa dan dinamika kelas.

1. Kurikulum

Sebuah kelas tidak boleh sekedar diartikan sebagai tempat siswa berkumpul untuk mempelajari sejumlah ilmu pengetahuan. Demikian juga sebuah sekolah bukanlah sekedar sebuah gedung tempat siswa mencari dan mendapatkan ilmu pengetahuan. Sekolah dan kelas diselenggarakan untuk memenuhi kebutuhan masyarakat dalam mendidik siswa-siswa yang tidak hanya didewasakan dari segi intelektualitasnya saja, akan tetapi dalam seluruh aspek kepribadiannya. Untuk itu bagi setiap tingkat dan jenis sekolah diperlukan kurikulum yang mampu memenuhi kebutuhan masyarakat yang semakin kompleks dalam perkembangannya. Kurikulum yang dipergunakan di sekolah sangat besar pengaruhnya terhadap aktifitas kelas dalam mewujudkan proses belajar mengajar yang berdaya guna bagi pembentukan pribadi siswa. Zakiah Daradjat (1996:83) menyebutkan bahwa "kurikulum adalah semua kegiatan yang memberikan pengalaman kepada siswa (anak didik) di bawah bimbingan dan tanggung jawab sekolah, baik di luar maupun di dalam lingkungan dinding sekolah".

2. Gedung dan Sarana Kelas

Perencanaan dalam membangun sebuah gedung untuk sebuah sekolah berkenaan dengan jumlah dan luas setiap ruangan, letak dan dekorasinya yang harus disesuaikan dengan kurikulum yang dipergunakan. Akan tetapi karena kurikulum selalu dapat berubah sedang ruangan atau gedung bersifat permanen, maka diperlukan kreatifitas dalam mengatur pendayagunaan ruang/gedung.

3. Guru

Program kelas tidak akan berarti bilamana tidak diwujudkan menjadi kegiatan. Untuk itu peranan guru sangat menentukan karena kedudukannya sebagai pemimpin pendidikan diantara siswa-siswa dalam suatu kelas. Guru adalah seseorang yang ditugasi mengajar sepenuhnya tanpa campur tangan orang lain (A. Tabrani Rusyan ,2001:135).

4. Siswa

Siswa merupakan potensi kelas yang harus dimanfaatkan guru dalam mewujudkan proses belajar mengajar yang efektif. Siswa adalah anak-anak yang sedang tumbuh dan berkembang, dan secara psikologis dalam rangka mencapai tujuan pendidikannya melalui lembaga pendidikan formal, khususnya berupa sekolah. Siswa sebagai unsur kelas memiliki perasaan kebersamaan yang sangat penting artinya bagi terciptanya situasi kelas yang dinamis.

5. Kelas

Kelas adalah kelompok sosial yang dinamis yang harus dipergunakan oleh setiap guru kelas untuk kepentingan siswa dalam proses kependidikannya. Dinamika kelas pada dasarnya berarti kondisi kelas yang diliputi dorongan untuk aktif secara terarah yang dikembangkan melalui kreativitas dan inisiatif siswa sebagai suatu 
kelompok. Untuk itu setiap wali atau guru kelas harus berusaha menyalurkan berbagai saran, pendapat, gagasan, keterampilan, potensi dan energi yang dimiliki siswa menjadi kegiatan-kegiatan yang berguna.

\section{E. Hubungan Media Pembelajaran Dengan Suasana Pembelajaran.}

Media befungsi sebagai sarana yang dapat memberikan pengalaman visual kepada siswa untuk mendorong motivasi belajar, memperjelas dan mempermudah konsep yang abstrak dan mempertinggi daya serap. Hamalik seperti yang dikutip Azhar Arsyad (2003:15) mengemukakan bahwa pemakaian media pengajaran dalam proses belajar mengajar dapat membangkitkan keinginan dan minat yang baru, membangkitkan motivasi dan rangsangan kegiatan belajar dan bahkan membawa pengaruh-pengaruh psikologis terhadap siswa. Sementara itu, Derek Rowntree menyatakan bahwa media pendidikan berfungsi untuk membangkitkan motivasi belajar, mengulang apa yang telah dipelajari, menyediakan stimulus belajar, mengaktifkan respon anak, memberikan balikan dengan segera.

Berkaitan hubungan media dengan suasana belajar Rusman (2009:151) mengatakan bahwa bila guru telah melakukan kegiatan pembelajaran hanya menggunakan verbal symbol atau one way communication, ini belumlah optimal dalam mencapai kompetensi yang diharapkan. Hasil penelitian BAVA di Amerika Serikat menegaskan bahwa bila seorang guru atau tenaga pendidik yang mengajar hanya menggunakan verbal symbol (ceramah murni), maka materi yang terserap hanya $13 \%$ dan itu pun tidak akan bertahan lama, sementara yang menggunakan multimedia bisa mencapai 64 sampai $84 \%$ dan bertahan lama. Hal ini menunjukkan bahwa penggunaan media sangatlah besar pengaruhnya dalam meningkatkan perhatian, motivasi, dan peningkatan kualitas pembelajaran.

Dengan melihat manfaat dan kegunaan dari penggunaan media dalam proses pembelajaran, maka akan menciptakan suasana belajar yang aktif, inovatif, kreatif, efektif dan menyenangkan.

\section{METODE PENELITIAN}

Jenis Penelitian yang digunakan adalah Penelitian kepustakaan (Library Research) yaitu "pengumpulan dan penganalisaan bahan-bahan perpustakaan yang bersumber dari pemikiran para tokoh pendidikan, buku-buku dan berbagai literatur lainnya yang ada hubungannya dengan pokok masalah pembahasan".

Sumber data yang digunakan dalam metode ini adalah sumber data primer berupa jurnal-jurnal yang erat kaitannya dengan pendidikan khususnya penggunaan media proyektor dalam pembelajaran I.P.A. Sedangkan data sekunder adalah data yang diperoleh atau bersumber dari tangan kedua (second hand data). Atau yang tidak berkaitan langsung dengan pembahasan, seperti; buku-buku, majalah dan lain sebagainya.

Teknik pengumpulan data yang ditempuh oleh penulis dengan teknik dokumen resmi eksternal yang berisikan bahan-bahan informasi yang dihasilkan oleh suatu lembaga sosial, misalnya majalah, bulletin, pernyataan dan berita yang disiarkan kepada media massa. Adapun dokumen tersebut berbentuk jurnal-jurnal yang dipublikasikan.

Tehnik Analisa yang digunakan adalah tehnik Deskriptif Analisis, Suatu data yang sudah terkumpul kemudian diindentifikasikan, klasifikasikan dan di uraikan secara sistematik dan logis kemudian diolah dengan menggunakan metode deskriptif analisis. Dalam membahas permasalahan ini, penulis menyelidiki jurnal-jurnal yang berkaitan dengan tema penelitian. Metode deskriptif ini digunakan untuk mendeskripsikan optimalisasi penggunaan proyektor dalam pembelajaran pada mata pelajaran I.P.A. 


\section{HASIL DAN PEMBAHASAN}

Dari paparan di atas penulis dapat menarik kesimpulan bahwa penggunaan media belajar proyektor dalam pelajaran I.P.A dapat meningkatkan minat, motivasi siswa dalam belajar sehingga memberikan dampak yang positif dalam peningkatan prestasi siswa.

\begin{tabular}{|c|c|c|c|c|c|}
\hline No & Penulis & Judul & Hasil & Metode & Nama Jurnal \\
\hline 1 & $\begin{array}{l}\text { Steffi } \\
\text { Adam } \\
\text { dan } \\
\text { Muhamm } \\
\text { ad Taufik } \\
\text { Syastra, } \\
2015\end{array}$ & $\begin{array}{l}\text { Pemanfaatan } \\
\text { media pembelajaran } \\
\text { berbasis teknologi } \\
\text { informasi Bagi siswa } \\
\text { kelas x SMA } \\
\text { Ananda Batam }\end{array}$ & $\begin{array}{l}\text { Pemanfataan media } \\
\text { pembelajaran berbasis } \\
\text { teknologi informasi bagi } \\
\text { siswa kelas X SMA } \\
\text { Ananda Batam sebesar } \\
76,94 \% \text { dari nilai yang } \\
\text { diharapkan. }\end{array}$ & $\begin{array}{c}\text { Statistik } \\
\text { Deskriptif }\end{array}$ & $\begin{array}{l}\text { CBIS } \\
\text { Journal, } \\
\text { Volume } \\
\text { No } 2\end{array}$ \\
\hline 2 & $\begin{array}{l}\text { Joko } \\
\text { Sarminto }\end{array}$ & $\begin{array}{l}\text { Pengaruh } \\
\text { penggunaan media } \\
\text { pembelajaran lcd } \\
\text { Proyektor terhadap } \\
\text { hasil belajar siswa } \\
\text { Pada mata pelajaran } \\
\text { ekonomi }\end{array}$ & $\begin{array}{l}\text { Penggunaan media } \\
\text { pembelajaran LCD } \\
\text { Proyektor di SMA Negeri } \\
9 \text { Pontianak termasuk } \\
\text { dalam kategori baik. } \\
\text { Hasil belajar siswa pada } \\
\text { mata pelajaran ekonomi } \\
\text { kelas X di SMA Negeri } 9 \\
\text { Pontianak termasuk } \\
\text { kategori sudah baik. }\end{array}$ & Deskriptif & $\begin{array}{l}\text { Program } \\
\text { Studi } \\
\text { Pendidikan } \\
\text { Ekonomi } \\
\text { FKIP } \\
\text { UNTAN, } \\
\text { Pontianak }\end{array}$ \\
\hline 3 & $\begin{array}{l}\text { Ahmad } \\
\text { Fatkhul } \\
\text { Huda. } \\
2014\end{array}$ & $\begin{array}{l}\text { Penerapan media } \\
\text { pembelajaran } \\
\text { berbasis multimedia } \\
\text { Lcd proyektor dalam } \\
\text { upaya meningkatkan } \\
\text { motivasi } \\
\text { Belajar ipa siswa } \\
\text { kelas IV SDN I } \\
\text { Taruman Tahun } \\
\text { ajaran 2013/2014 }\end{array}$ & $\begin{array}{l}\text { Meningkatkan motivasi } \\
\text { belajar pada mata } \\
\text { pelajaran IPA ditandai } \\
\text { dengan meningkatnya } \\
\text { indikator motivasi belajar } \\
\text { dari pra siklus sampai } \\
\text { siklus II diantaranya: a). } \\
\text { memperhatikan } \\
\text { penjelasan guru sebelum } \\
\text { tindakan } 57,89 \% \text { setelah } \\
\text { tindakan menjadi } \\
94,73 \% \text {. } \\
2 . \\
\text { belajar seningkat hasil } \\
\text { dilihat dari nilai pra } \\
\text { siklus siswa yang tuntas } \\
\text { sebanyak } 4 \text { siswa atau } \\
21,05 \% \text { pada siklus I } \\
\text { meningkat menjadi } 10 \\
\text { siswa atau } 52,63 \% \text { dan } \\
\text { pada siklus II meningkat } \\
\text { lagi menjadi } 17 \text { siswa } \\
\text { atau } 89,47 \% \text {. }\end{array}$ & $\begin{array}{l}\text { Deskriptif } \\
\text { kualitatif }\end{array}$ & $\begin{array}{l}\text { Jurnal } \\
\text { skripsi } \\
\text { Universitas } \\
\text { Muhammadi } \\
\text { yah } \\
\text { Surakarta }\end{array}$ \\
\hline 4 & Ningsih.2 & Peningkatan & Hasil belajar yang & PTK & Jurnal \\
\hline
\end{tabular}

Siska Nasfa Ayu Sulastri, Hanifuddin Jamin dan Maya Agustina, Optimalisasi penggunaan proyektor ... . 73 


\begin{tabular}{|c|c|c|c|c|c|}
\hline & 012 & $\begin{array}{l}\text { belajar IPA melalui } \\
\text { penggunaan } \\
\text { Media pembelajaran } \\
\text { interaktif di kelas V }\end{array}$ & $\begin{array}{l}\text { menggunaan media CD } \\
\text { pembelajaran interaktif } \\
\text { baik sekali digunakan } \\
\text { untuk meningkatkan } \\
\text { kualitas proses } \\
\text { pembelajaran IPA. Hal } \\
\text { ini ditunjukkan dengan } \\
\text { meningkatnya tes hasil } \\
\text { belajar IPA tentang alat } \\
\text { pencernaan manusia. }\end{array}$ & & $\begin{array}{l}\text { Perspektif } \\
\text { Ilmu } \\
\text { Pendidikan, } \\
\text { Vol. } 25 \text { Th. } \\
\text { XVI }\end{array}$ \\
\hline 5 & $\begin{array}{l}\text { Moh. } \\
\text { Akbar. } \\
\text { t.th. }\end{array}$ & $\begin{array}{l}\text { Pemanfaatan Media } \\
\text { Lcd Proyektor } \\
\text { Terhadap Minat } \\
\text { Belajar Siswa Dalam } \\
\text { Pembelajaran PKN } \\
\text { Di Kelas VIII SMP } \\
\text { Negeri 4 Palu }\end{array}$ & $\begin{array}{l}\text { Pemanfaatan Media LCD } \\
\text { Proyektor di SMP Negeri } \\
4 \text { Palu adalah dampaknya } \\
\text { terhadap minat belajar } \\
\text { siswa dalam } \\
\text { Pembelajaran PKn. }\end{array}$ & Kuantitatif & $\begin{array}{l}\text { Jurnal } \\
\text { Skripsi } \\
\text { Universitas } \\
\text { Tadulako. }\end{array}$ \\
\hline 6 & $\begin{array}{l}\text { Fatikhatu } \\
\text { n } \\
\text { Najikhah. } \\
2016\end{array}$ & $\begin{array}{lr}\text { Keefektifan } & \text { MPI } \\
\text { Game } & \text { Edukasi } \\
\text { Terhadap } & \text { Hasil } \\
\text { Belajar IPA di Kelas } \\
\text { 1 Sekolah Dasar, }\end{array}$ & $\begin{array}{l}\text { Penerapan penggunaan } \\
\text { pembelajaran } \\
\text { menggunakan MPI game } \\
\text { edukasi dengan Adobe } \\
\text { Flash untuk pembelajaran } \\
\text { IPA siswa kelas } 1 \text { sudah } \\
\text { efektif digunakan untuk } \\
\text { meningkatkan hasil } \\
\text { belajar pembelajaran IPA } \\
\text { dengan indikasi adanya } \\
\text { perbedaan antara nilai } \\
\text { sebelum menggunakan } \\
\text { media dan sesudah } \\
\text { menggunakan media. } \\
\text { dengan rata-rata nilai } \\
\text { peningkatan sebesar } \\
20,36 \% \text {. }\end{array}$ & Eksperimen & $\begin{array}{l}\text { Jurnal: } \\
\text { Indonesian } \\
\text { Journal of } \\
\text { Curriculum } \\
\text { and } \\
\text { Educational } \\
\text { Technology } \\
\text { Studies, } \\
\text { Vol. 4, } \\
\text { Tahun 2016. }\end{array}$ \\
\hline 7 & $\begin{array}{l}\text { Nur } \\
\text { Rohman. } \\
2018\end{array}$ & $\begin{array}{l}\text { Efektifitas } \\
\text { Pembelajaran } \\
\text { Berbasis Led } \\
\text { Projector Dengan } \\
\text { Model Pembelajaran } \\
\text { Kontekstual } \\
\text { Terhadap Prestasi } \\
\text { Belajar Mahasiswa. }\end{array}$ & $\begin{array}{l}\text { Pembelajaran berbasis } \\
\text { LCD proyektor dengan } \\
\text { model pembelajaran } \\
\text { kontekstual lebih efektif } \\
\text { memberikan prestasi } \\
\text { belajar mahasiswa IKIP } \\
\text { PGRI Bojonegoro } \\
\text { dibanding } \\
\text { pembelajaran dengan } \\
\text { konvensional pada mata } \\
\text { kuliah perencanaan } \\
\text { pembelajaran tahun } \\
\text { akademik 2017/2018. }\end{array}$ & Kuantitatif & $\begin{array}{l}79 \text { Jurnal } \\
\text { Pendidikan } \\
\text { EDUTAMA } \\
\text {, Vol 5, No. } \\
\text { 2, Juli 2018. }\end{array}$ \\
\hline 8 & $\begin{array}{l}\text { Robi Dwi } \\
\text { Nugraha. } \\
2014\end{array}$ & $\begin{array}{lr}\text { Pengaruh } & \\
\text { Penggunaan } & \text { Media } \\
\text { Pembelajaran } & \text { Lcd }\end{array}$ & $\begin{array}{lr}\text { penggunaan } & \text { media } \\
\text { pembelajaran } & \text { LCD } \\
\text { proyektor dikategorikan }\end{array}$ & Eksperimen & $\begin{array}{l}\text { Jurnal } \\
\text { Skripsi } \\
\text { Universitas }\end{array}$ \\
\hline
\end{tabular}




\begin{tabular}{|c|c|c|c|c|c|}
\hline & & $\begin{array}{l}\text { Proyektor Terhadap } \\
\text { Minat Belajar Siswa } \\
\text { Dalam Pendidikan } \\
\text { Agama Islam Di } \\
\text { Sekolah Menengah } \\
\text { Pertama Negeri 1 } \\
\text { Tambang, }\end{array}$ & $\begin{array}{l}\text { Sangat Baik dengan } \\
\text { persentase } 81,42 \% \text {. Dan } \\
\text { hasil dari pengolahan } \\
\text { data ada pengaruh yang } \\
\text { signifikan } \\
\text { penggunaan antara } \\
\text { pembelajaran media } \\
\text { Proyektor terhadap minat } \\
\text { belajar siswa. }\end{array}$ & & $\begin{array}{l}\text { Islam } \\
\text { Negeri } \\
\text { Sultan } \\
\text { Syarif } \\
\text { Kasim Riau, } \\
2017 .\end{array}$ \\
\hline 9 & $\begin{array}{l}\text { Sindi Eka } \\
\text { Setia } \\
\text { Pranata. } \\
2014\end{array}$ & $\begin{array}{lr}\text { Penerapan } & \\
\text { Multimedia Berbasis } \\
\text { Komputer } & \text { Dan Lcd } \\
\text { Proyektor } & \text { Terhadap } \\
\text { Hasil } & \text { Belajar } \\
\text { Passing } & \text { Bawah } \\
\text { Bolavoli } & \text { Pada } \text { Anak } \\
\text { Tunarungu } \quad \text { (Studi } \\
\text { Pada Siswa Kelas X } \\
\text { Smalb Tunarungu } \\
\text { Dharma } & \text { Wanita } \\
\text { Sidoarjo), } & \end{array}$ & $\begin{array}{l}\text { Pengaruh penggunaan } \\
\text { penerapan multimedia } \\
\text { berbasis komputer dan } \\
\text { LCD proyektor terhadap } \\
\text { hasil belajar passing } \\
\text { bawah bolavoli pada } \\
\text { siswa kelas X di SMALB } \\
\text { Tunarungu Dharma } \\
\text { Wanita. Hasil belajar } \\
\text { adalah } 14,78 \% \text {. }\end{array}$ & Eksperimen & $\begin{array}{l}\text { Jurnal } \\
\text { Pendidikan } \\
\text { Olahraga } \\
\text { dan } \\
\text { Kesehatan } \\
\text { Volume } 02 \\
\text { Nomor } 03 \\
\text { Tahun } 2014 .\end{array}$ \\
\hline 10 & $\begin{array}{l}\text { Iman } \\
\text { Nasrulloh } \\
.2017\end{array}$ & $\begin{array}{l}\text { Analisis Kebutuhan } \\
\text { Pembelajaran } \\
\text { Berbasis ICT. }\end{array}$ & $\begin{array}{lr}\text { Faktor-faktor } & \text { yang } \\
\text { dibutuhkan } & \text { dalam } \\
\text { pembelajaran } & \text { berbasis } \\
\text { ICT, yaitu: } & 1 \text { ) } \\
\text { kemampuan } & \text { merancang } \\
\text { pembelajaran } & \text { berbasis } \\
\text { online; 2) } & \text { Pentingnya } \\
\text { pelaksanaan } & \text { pelatihan } \\
\text { guru sebagai } & \text { upaya } \\
\text { peningkatan } & 3) \\
\text { kemampuan menerapkan } \\
\text { konsep pada situasi baru } \\
\text { dengan cara } \\
\text { berbeda yang }\end{array}$ & - & $\begin{array}{l}\text { Jurnal } \\
\text { PETIK } \\
\text { Volume } \quad 3, \\
\text { Nomor } 1, \\
\text { Maret } 2017 .\end{array}$ \\
\hline
\end{tabular}




\section{PENUTUP}

Dari pembahasan yang telah dilakukan pada bab-bab terdahulu maka penulis dapat menyimpulkan bahwa:

1. Penggunaan media proyektor dalam pembelajaran I.P.A mempunyai manfaat atau kegunaan proyektor dalam proses pembelajaran diantaranya

a. Sebagai alat presentasi. Proyektor dapat membuat sebuah presentasi menjadi lebih hidup, karena dengan tampilan gambar atau tulisan itu memberikan presentasi yang lebih dinamis dan atraktif.

b. Sebagai Media Informasi. Bisa menampilkan tampilan dengan layar besar, maka proyector sangatlah efektif untuk dijadikan sebagai media informasi.

c. Sebagai pemutar Video. Bisa menikmati bioskop di dalam rumah. Hal ini dikarenakan proses tampilan yang terjadi di bioskop dapat ditampilkan di rumah, yaitu dengan proyeksi.

2. Penggunaan media belajar proyektor pada mata pelajaran I.P.A dapat meningkatkan minat, motivasi siswa dalam belajar sehingga memberikan dampak yang positif dalam peningkatan prestasi siswa. 


\section{DAFTAR PUSTAKA}

Ahmadi, Abu dan Joko Tri Prasetia, Strategi Belajar Mengajar, Bandung, Pustaka Setia, cet.II, 2005.

Arsyad, Azhar, Media Pembelajaran, ed.1, Cet. V, Jakarta: Raja Grafindo Persada, 2003.

Bahri Djamarah, Syaiful dan Aswan Zein, Strategi Belajar Mengajar, Jakarta: Rineka Cipta, 2006.

Daradjat, Zakiah, dkk, Metodologi Pengajaran Agama Islam, Jakarta: Bumi Aksara, 1996.

Faruqi, Dwi, Upaya Meningkatkan Kemampuan Belajar Siswa Melalui Pengelolaan Kelas, Dalam Jurnal Evaluasi. Vol.2, No. 1, Maret 2018.

Nata, Abuddin, Perspektif Islam tentang Strategi Pembelajaran, Jakarta: Kencana, 2009.

Ningsih, Peningkatan hasil belajar IPA melalui penggunaan Media pembelajaran interaktif di kelas V, Jurnal Perspektif Ilmu Pendidikan, Vol, 25 Th. XVI, Tahun 2012.

Permendiknas Nomor 22 Tahun 2006, Tentang Standar Isi.

Rusman, Manajemen Kurikulum, Cet.1, Jakarta: Rajagrafindo Persada, 2009.

Rusyan, A. Tabrani, Pendekatan Dalam Proses Belajar Mengajar, Bandung; Remaja Karya, 2001.

Sadiman, Arief, Media Pendidikan: Pengertian, Pengembangan, Dan Pemanfaatan, Jakarta : Grafindo Pers, 2000.

Sarminto, Joko, et.al, Pengaruh Penggunaan Media Pembelajaran Lcd Proyektor Terhadap Hasil Belajar Siswa Pada Mata Pelajaran Ekonomi, Jurnal Program Studi Pendidikan Ekonomi FKIP UNTAN, Pontianak.

Surachman, Winarno, Dasar dan Teknik Mengajar dan Belajar, Bandung: Tarsito, 2003.

Utami, Yulia, Pengaruh Pemanfaatan Media Pembelajaran Proyektor Lcd Menggunakan Program Power Point Terhadap Hasil Belajar Siswa Dalam Menentukan Volume Kubus Dan Balok Pada Bangun Ruang, Volume 1 No 1 Juli 2017. 